January 2019

\title{
Who Votes for Libraries?
}

\author{
Patrick Sweeney \\ EveryLibrary, patrick.sweeney@everylibrary.org
}

Follow this and additional works at: https://scholarworks.sjsu.edu/ischoolsrj

Part of the American Politics Commons, Collection Development and Management Commons, and the Scholarly Publishing Commons

Acknowledgements

\section{Recommended Citation}

Sweeney, P. (2019). Who Votes for Libraries?. School of Information Student Research Journal, 8(2). https://doi.org/10.31979/2575-2499.080202 Retrieved from https://scholarworks.sjsu.edu/ischoolsrj/ vol8/iss $2 / 2$

This article is brought to you by the open access Journals at SJSU ScholarWorks. It has been accepted for inclusion in School of Information Student Research Journal by an authorized administrator of SJSU ScholarWorks. For more information, please contact scholarworks@sjsu.edu. 


\title{
Who Votes for Libraries?
}

\section{Keywords}

public libraries, politics, funding, EveryLibrary, PACs, voting

\section{Acknowledgements}

\begin{abstract}
About Author
Patrick Sweeney is a 2007 graduate of the San Jose School of Library and Information Sciences and the a former Administrative Librarian of the Sunnyvale (CA) Public Library and previously was Executive Director of EveryLibrary California, a statewide initiative to support library Propositions. He has been a lecturer at the San Jose Information School where he taught courses on political activism and libraries. $\mathrm{He}$ is co-founder of the Library Think Tank. His library blog is well respected, and he is a sought-after speaker and presenter. A recent project, the Story Sailboat, worked to provide library services and materials - by boat - in the San Francisco Bay area. He tweets at @pcsweeney.
\end{abstract}




\section{WHO VOTES FOR LIBRARIES?}

In 2008 the OCLC released its report "From Awareness to Funding: A Study of Library Support in America," which was a groundbreaking study on voter, funder, and advocate attitudes and behaviors about libraries. Through a series of public surveys and focus groups, the OCLC unearthed the first, and still the richest, profile of what motivates people to support a library, and what demographic characteristics matter when segmenting the public into Super Supporters, Probable Supporters, and other categories. While the research work in "From Awareness to Funding" was done before the Great Recession, before President Obama, before the Tea Party, and before the presidency of Donald Trump, much of the data about the voters themselves that the report uncovered has remained surprisingly consistent since publication.

'In 2018 the OCLC and the American Library Association collaborated on a second study about voter behavior and support for libraries. This report has come ten years after the original 2008 study and is entitled "From Awareness to Funding: Voter Perceptions and Support of Public Libraries in 2018." While the original study looked at the awareness, attitudes, and underlying motivations of American voters for supporting library funding, this new report was significant because it was the first time that anyone had looked at the voters' shifting attitudes about library funding. With two reports, ten years apart, we finally have insight into the changing trends of voter attitudes about libraries and not just a single-study snapshot. Unfortunately, the trend that was discovered was an indication that library funding through ballot measures is at risk because voters are now far less likely to vote "yes" for libraries than they were ten years ago. In fact, we lost about 16 percent of our strongest supporters.

In my work at EveryLibrary, I have found that the conclusions from the study are almost identical to what we see in the field during library campaigns. EveryLibrary is the first and only National Political Action Committee for libraries. Our work is primarily focused on helping libraries win local elections. This work is critical because over $90 \%$ of library funding is dependent on the will of local voters and local politicians. In the last six years, we have worked on nearly 100 campaigns, and in many cases, we are able to run local public opinion polling that asks similar questions to those in the OCLC study. In each of those public opinion polls we find that there are some outlying data points that reflect some of the local issues in politics, but for the most part, we have seen a measurable decline in voter willingness to vote yes for libraries.

This should be significantly disturbing to our industry because without that voter support for library funding, libraries will no longer have the resources to keep their doors open. In order to maintain our funding, we need to understand who votes for libraries and why Americans support libraries at the ballot box. Without answering those questions, we will never be able to reverse the trends in declining support on election day.

The 2008 and 2018 "From Awareness to Funding" studies have provided us with a series of guideposts to identify people in every kind of community who are predisposed to help but have not yet been activated in support of the library. 
These guideposts are important because we can align our marketing, outreach, and networking to first identify and then activate those supporters well ahead of a ballot measure. These potential supporters hold views about libraries as an institution, about the librarians themselves, and they even share a common worldview, outlook, or attitude. These views are cultural and philosophical attitudes that cut across demographic boundaries and supersede party affiliations.

In the 2008 "From Awareness to Funding" report, the research identified a set of "shared values and beliefs" among the people who make up the Probable Supporter and the Super Supporter segments:

- They are involved in their communities.

- They recognize the library's importance to the community and to children's education.

- They are not always heavy users of the library, but they believe the library is a noble place, and one that is important and relevant to the community.

- They see the library as a vital community resource like public schools, fire departments, and police, and they are willing to increase their taxes in order to support the library.

- They recognize the value of a "passionate librarian" as a true advocate for lifelong learning.

Let us look at each of these shared characteristics in detail.

\section{They are involved in their communities.}

When we present this key voter characteristic to a library leadership team, they usually look around the room and think "Well, this is all of us then." We have to remind them that library supporters do not necessarily have to be involved with the library in order to be supporters on Election Day. They simply have to be involved in their own community. This does not necessarily mean that they go to city council meetings or write letters to the editor about civic issues. It does mean that they have a "community of intention" that they care about. For example, it could be their volunteer work for a social organization or club, or it could be through their place of worship. Many of them are easily identified as members of the PTA or PTO, but we should not overlook the volunteer coaches, theater and arts families, band boosters, and after-school parents. In libraries, we have an advantage in identifying these people who are "involved with their communities" because so many of their intentional communities meet at the library and use the library. These people are relatively easy to find, and they are predisposed to hearing about how your budget or your building impacts their community. They also have empathy for other groups in the community that need a librarian too.

\section{They recognize the library's importance to the community and to children's education.}

We have a fairly robust vocabulary in libraries to talk about our impacts on pre-K, $\mathrm{K}-12$, and lifelong learning in libraries. Librarians know the power of information 
literacy. We understand that the crucial reason why we teach kids to read is so that they can read to learn. Summer reading has transformed into a Summer Learning program for so many libraries precisely because libraries are well-equipped to help bridge the Summer Gap. Library supporters are eager to hear about this high-impact work we do. They are primed to appreciate it, and they are willing to talk about better funding to extend it.

Where we sometimes fail as library communities is to get beyond a great educational message and share what our impacts are on other populations. What we need to do to help our library ballot campaigns from the beginning is to articulate the importance of the library to the wider community. Too often, library leaders talk first and foremost about the library's impact on education and on children to audiences that do not look at education as their primary mission. While we would like to think that everyone can understand and value the work librarians do with pre-K children, for many of the community-minded volunteers, supporters, and voters you are trying to activate, pre- $\mathrm{K}$ issues are simply not their main concern.

The hidden strength of libraries is that we already do so many things for so many different types of voters that we should be ready, quickly, to tell better stories about this. Take, for example, how libraries should be marketing and highlighting their services to veterans in the lead-up to an election. Programs for veterans are integral parts of library services, but we know from our campaigns that this fact is not well known outside of the groups of voters who were directly served. Library leaders need to start marketing their services, and not just to voters who may need those services. In some towns, the number of vets who could use the service directly might be relatively small. In other localities, there are multiple generations of veterans in residence with different needs based on their age and their stage in the homecoming process. When marketing a new veteran-focused service to potential users, we would recommend talking with local chapters of the Veterans of Foreign Wars and the American Legion or notifying clergy and counseling centers about a new high-impact program for returning vets. But we are also interested in seeing our libraries talk to voters who are not military themselves about how the local library supports their neighbors who served in the armed forces. It it not a heartstrings story, but as vets find what they need from librarians, you should record and retell those stories. The fact that the library supports veterans who are looking for work or continuing their education is a compelling story that non-users might want to know. It is a story about how we care for our own and about how a part of government is putting taxes to good, smart, leverage-able uses.

\section{They are not always heavy users of the library, but they believe the library is a noble place, one that is important and relevant to the community.}

Nothing in this finding indicates that the Probable or Super Supporters recognize the library's importance to themselves personally or that they even use the library at all. This country is littered with library buildings named after families who were too rich to need what was inside the library itself. They donated money to the library even though they do not use it because they wanted to see libraries founded and built for the benefit of their community. While one could speculate that perhaps 
Andrew Carnegie did what he did, so the mob would not rise up against him, we suspect that he was true to his word about why he donated so much to establish so many libraries. In the April issue of the Library Journal in the year 1900, Andrew Carnegie said this about funding libraries:

"I choose free libraries as the best agencies for improving the masses of the people, because they give nothing for nothing. They only help those who help themselves. They never pauperize. They reach the aspiring, and open to those the chief treasures of the world-those stored up in books."

People from all walks of life donate money to build, furnish, and equip libraries even if they do not plan to be users. Whether you call your users "patrons," "customers," or "members" does not matter. The voter who is a user can certainly understand a marketing message about what a "yes" vote would mean to him or her. Nonvoters who are users who can understand this too, but we are not concerned with nonvoters if we are talking about library funding. We are concerned with voters who are non-users. These are the people in your community who will decide on the fate of the library ballot measure and who do not have any personal "What is in it for me?" perspective about the election because they do not utilize the library.

Those non-users who are "yes" voters for the library vote the way they do because they believe in the library as an institution, and in librarians as change agents. And they do not have any reasonable reason to believe the way that they do until we educate them about why they should believe in libraries. That's because, having not been in the library since they themselves were children or teens, they lack a current awareness and understanding of the library. And yet they persist in their belief that something good, something noble even, happens there. They are willing to vote for the resources that librarians need to do good work at that important place. They cannot be appealed to on the basis of their own self-interest in improving the user experience. They do not have a user experience.

They need to be addressed by your campaign with an understanding - and an appreciation - that they are empathetic people.

We do not believe that this empathy makes them liberals or progressives in the current political usage any more than folks who are conservatives or independents lack empathy or compassion. In fact, nothing in either of the "From Awareness to Funding" reports' data suggests any difference between traditional party affiliations or leanings for "conservatives" or "liberals" in their proclivity to vote for the library. There is little or no difference between the success or failure of library ballot measures between Red and Blue states over the last few years. The key differentiator about the Tea Party or Libertarians is not who they voted for at the top of the ticket in the last election, but instead is the fact that they hold a philosophy of government that does not include progressive taxation. They are not "against" the library and in fact, we have seen significant support for libraries come from those holding libertarian viewpoints when they are educated about the nature and benefits of library funding in an open and transparent way. 
We need to understand that the margin of difference between a yes and no vote is not about voter demographics or political parties. It is about the way that librarians communicate with their communities of voters. Libraries must frame their communications from the earliest stage with this awareness in mind. First off, if all of your library marketing is set up to encourage people to become library users, we know that this will backfire. To require someone to become a library user in order to be a valid library supporter or voter can set up a very strong emotional barrier to their support. If your marketing is exclusively focused on non-users changing their behavior (by using the library) instead of validating their beliefs, you can run into two problems: people do not like to change their behaviors; and, if their beliefs are in conflict with your expectations, they will not like you. In the lead-up to Election Day, please do not require your non-users to start using the library. They do not need to experience your work firsthand in order to care about the work you do. They are capable of voting "yes" for the library without having a library card. That is why your communications around voting for libraries must focus directly on increasing support, and not on increasing library use in order to build support.

\section{They see the library as a vital community resource like public schools, fire departments, and police, and they are willing to increase their taxes to support the library.}

The phrase "willing to increase their taxes" is an indicator that any library ballot measure has a chance of success. It may be difficult under many circumstances to win a ballot measure, but given enough hard work and shrewd tactics, it is not impossible. It just takes campaigners who are committed to doing the hard work. Finding common ground for political outcomes is often described as the "art of the possible." But if campaigners are unwilling to have a conversation about taxes that includes a simple openness to entertain a possible increase, then no budget or building referendum will ever get to the ballot. When libraries are unwilling to even discuss any increase in taxes, for any purpose whatsoever, then a library ballot measure really does become impossible. Remembering that some part of your electorate sees the library as a "vital community resource" means framing your conversations about the hopes you have and the outcomes you expect with the goal of winning over as many voters as possible who are at least open to considering the possibility of a tax increase and it is about having open, honest, and transparent conversations about taxes for libraries.

It is sometimes important to inform or remind folks in town that their neighbors are indeed willing to increase their own taxes in order to support their public library's services and staff. You will need to do your own surveys and polls to determine the baseline extent of that willingness. In chapter 5 of our upcoming book from ALA Editions, "Before the Ballot," from which this article was taken, we have a chapter entitled, "Library as Cause," where we discuss the kinds of questions you need to ask to get answers about voter-willingness that will allow you to plan an effective information campaign. You can also look at more current resources than the 2008 OCLC report's statistics for assurances that support does 
indeed exist in America for its libraries. While the Pew Research Center's surveys do not publish cross-tabulations on voter status, there is a consistent and stable body of public opinion data against which you can compare your local results.

Another aspect of voters' value perception of libraries as existing on a continuum with police and fire, parks and recreation, and schools is that each of those institutions is valued, by large chunks of the electorate, based on voters' perceptions of them rather than on their personal experience with them. Each of those institutions has a record of service to the community. By way of example, the likely number of community members or voters who have had a personal experience with the police or fire department is probably relatively low. But the number of community members or voters who have a favorable perception of the police or fire department is likely to be pervasive. Public safety may have a reputation (positive or negative) in your community that it does not deserve, but the voters will, in the main, vote on public issues and support politicians when issues and leaders line up with their perceptions about — and not their personal experience of-safe communities.

The voters' perception of libraries as an institution matters in a similar way. Your library may or may not have a good reputation in town, but whatever reputation it has constitutes your record. If your voters are new to town and are not users, their reference point is the library from their hometown, as well as their abstract perception of "libraries." You may not be in control of your own library's record, but politicians run for office in one of two ways: on their own record or against their opponent's record. If the politician is an incumbent, the message is: "re-elect me and I'll continue to look out for you." If the candidate is an insurgent, the message is: "get rid of that politician and elect me. I know how to do it right for you." We suggest to library campaigns that they see their own record - the record for which voters are willing to talk about new taxes_as the incumbent's record in the campaign.

Library leaders need to make an early choice about either running a ballot measure "as the incumbent," meaning that they will communicate about the measure as a way to extend or enhance their record of success; or they need to run "against" their own library because a successful ballot measure would correct problems in the library and improve outcomes for the community. We would argue that you can successfully run against the library's record as the library when you are honest, engaged, and transparent about what you are trying to fix. The local opposition will always reference your library's record when messaging against a vote. We firmly believe that you need to embrace your record as the incumbent and define how you want to run the campaign messaging - "extend success" or "fix problems"- or the opposition will define it for you.

\section{They recognize the value of a "passionate librarian" as a true advocate for lifelong learning.}

The last key OCLC takeaway is a critical insight into voter perception that we do not think has penetrated far enough into the thinking and behavior of the library industry, or into the library advocacy ecosystem. The idea that voters have a 
perception of the library as an institution is really well understood within the library community. All of our marketing and outreach is designed around the "library." From the @yourlibrary campaign to "Geek the Library" to Libraries Transform, our advocacy campaigns have emphasized the noun library. It may be the library as a place, the library as a lifestyle, or the library as an idea. But that isn't the only noun we need. We also need to talk about the librarians. A critical takeaway for library leaders going to the ballot is that the library itself is only part of what is being voted on. The voters' recognition of librarians as passionate, engaged, and impactful people in their community is also on the ballot. The institutional incumbent record is being considered by the voters, but so are the humans who work there. We need to have a conversation about librarians that updates non-users' image of librarians.

While the OCLC's study's findings that we discussed are interesting and shed some light on voter support for libraries, we still have a lot of work to do to really begin understanding how to engage voters, so they support our organizations. These early studies were very useful because they began a dialogue that is long overdue in our industry. However, we still need to begin to understand how to segment these voters into their various demographics so that we can begin to have better conversations with them. Neither the 2008 study or the 2018 study provided that level of demographic data about our supporters. But now that we know why people might support libraries at the ballot box, our next step will be to begin to understand who supports libraries at the ballot box. We begin to explore this more in the book from which this article was excerpted. You can find it on the ALA Editions website or on Amazon. It is entitled, "Before the Ballot; Building Support for Library Funding." 


\section{References}

De Rosa, C., \& Johnson, J. (2008). From awareness to funding: A study of library support in America. Retrieved from https://www.oclc.org/research/publications/all/funding.html

OCLC, \& American Library Association. (2018). From awareness to funding:

Voter perceptions and support of public libraries in 2018. https://doi.org/10.25333/C3M92X 